\title{
Irregular schooling behavior and abandonment of mimicry by the Sabertooth Blenny (Blenniidae) in Cabo Pulmo National Park, Gulf of California, Mexico
}

Received: 1 September 2010/Accepted: 26 November 2010/Published online: 14 December 2010

(C) The Author(s) 2010. This article is published with open access at Springerlink.com
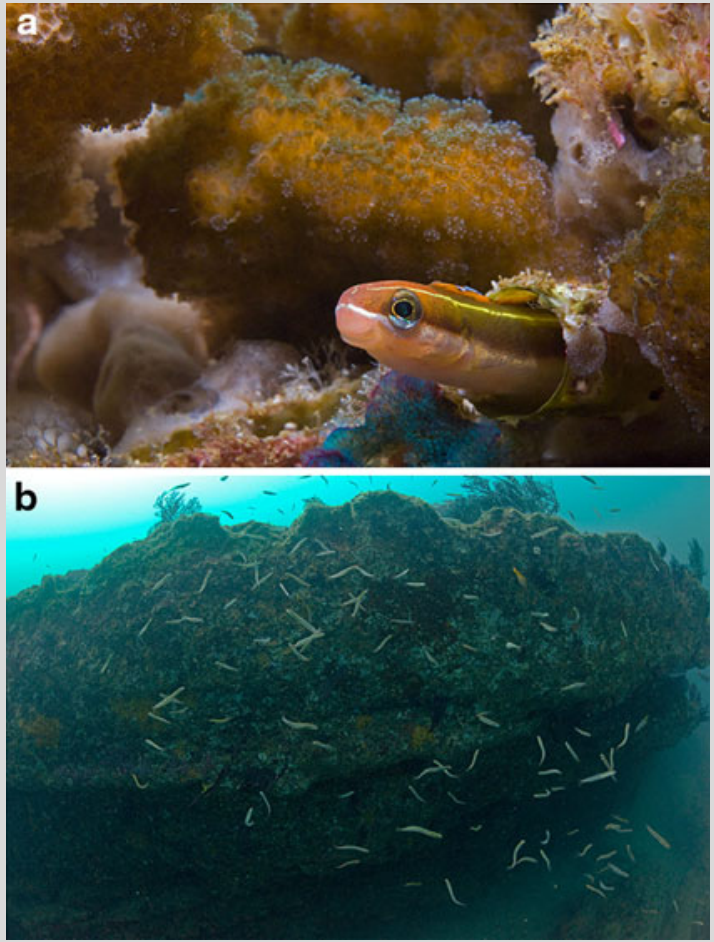

Fig. 1 The Sabertooth Blenny: $\mathbf{a}$ in a vacated invertebrate tube and b schooling in an aggregation of over 100 individuals. Note the light coloration atypical of individuals of this species engaged in mimicry. Photos by O. Aburto
Plagiotremus azaleus (the Sabertooth Blenny; Fig. 1a) is an obligate scale-eating blenny (Hobson 1968) endemic to and widespread in the tropical eastern Pacific. Like many members of Tribe Nemophini (Blenniidae), P. azaleus typically relies on mimicry to gain access to potential prey fishes (Smith-Vaniz 1976). Throughout its range, the model of this aggressive mimic is the initial phase of Thalassoma lucasanum (the Cortez Rainbow Wrasse). At several sites throughout the Gulf of California, we have observed $P$. azaleus in its typical mimic capacity, resembling its model in both appearance and behavior. On these reefs, $P$. azaleus is significantly outnumbered by $T$. lucasanum, with an average of more than 160 wrasses per blenny ( 2009 belt transect survey data). Distinguishing between the two is not difficult as the blennies are more slender and utilize anguilliform rather than labriform swimming, as in the wrasses. This typical difference in densities is not surprising given the necessary prevalence of the model and scarcity of the mimic in evolutionarily stable aggressive mimicry systems.

In summer and fall 2010, at reef sites in Cabo Pulmo National Park (CPNP), we observed several aggregations of $P$. azaleus ranging in number from 10 to 20 individuals and one group of well over 100 blennies (Fig. 1b). In contrast to our observations elsewhere, these blennies greatly outnumbered $T$. lucasanum, did not school with it, and did not display the dark coloration typical of individuals engaged in mimicry (Fig. 1). Instead, blennies from these groups aggressively attacked large fishes, including top predators such as Mycteroperca rosacea (Leopard Grouper) and Lutjanus novemfaciatus (Dog Snapper), in such large numbers and with such ferocity that they affected the behaviors and movements of these much larger fishes, displacing them from the area.

How a species that typically relies on mimicry can maintain such high local abundances without resembling its model is paradoxical. CPNP has been closed to fishing for 15 years and has some of the highest densities of reef fishes in the tropical eastern Pacific ( 2009 belt transect data). Perhaps these local abundances of potential prey allow for the large numbers of $P$. azaleus that we observed, even when they seemingly no longer utilize mimicry to gain access to food resources.

Open Access This article is distributed under the terms of the Creative Commons Attribution Noncommercial License which permits any noncommercial use, distribution, and reproduction in any medium, provided the original author(s) and source are credited.

\section{References}

Hobson ES (1968) Predatory behavior of some shore fishes in the Gulf of California. Research Report 73, Bureau of Sport Fisheries and Wildlife, U.S. Fish and Wildlife Service

Smith-Vaniz WF (1976) The Saber-toothed Blennies, Tribe Nemophini (Pisces: Blenniidae). Monograph 19. Academy of Natural Sciences of Philadelphia, Philadelphia, PA

\section{G. R. Galland $(\bowtie) \cdot$ O. Aburto-Oropeza · P. A. Hastings}

Center for Marine Biodiversity and Conservation, Marine Biology Research Division, Scripps Institution of Oceanography, University of California San Diego, La Jolla, CA 92093-0208, USA e-mail: ggalland@ucsd.edu

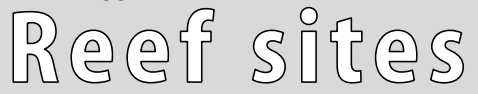

